\title{
Godnatt min näkkegal: Om dialektala uttalsformer av fågelbeteckningen näktergal
}

\section{Gunilla Söderberg}

Föreliggande artikel är en kommentar till ett begrepp i det sameuropeiska ordkarteringsprojektet Atlas Linguarum Europae, ALE. ${ }^{1}$ I Sverige är det Institutet för språk och folkminnen, Sofi, som ansvarar för projektet. De deltagande länderna arbetar med en gemensam frågelista - det gemensamma ALE-språket är franska. Svaret på varje fråga, eller begrepp som det också kallas, ska definieras så noggrant som möjligt. Ett viktigt hjälpmedel i detta arbete är Svenska Akademiens ordbok, SAOB, som är alla lexikografers bibel. När definitionen är klar, återstår att med hjälp av Sofi:s dialektsamlingar sammanställa de dialektala benämningarna på begreppet $\mathrm{i}$ fråga. ALE-projektet är alltså inriktat på själva orden. Uttal och böjning uppmärksammas inte, vilket dock inte hindrar att den som excerperar dialektmaterialet ändå kan notera sådana variationer.

I ALE-projektet representeras Sverige av 178 utvalda socknar, s.k. karteringspunkter, och de är jämnt fördelade över landet från Jokkmokk i norr till Ven (S:t Ibbs socken) i söder. Det är alltså dialekt- och ortnamnsarkivens antikvariska indelning av landet i socknar som tillämpas här. Det är inte säkert att det alltid finns dialektbelägg från karteringssocknen i fråga, och i sådana fall kan belägg från angränsande socknar användas. Förutsättningen är att det inte går någon dialektgräns mellan dessa socknar. Likväl händer att inte heller reservsocknarna har några belägg, och det uppkommer då en lakun. Alla landskap är inte lika väl upptecknade. Skåne, Blekinge, Halland och Småland är väl representerade i Sofi:s dialektarkiv, vilket dessvärre inte kan sägas om de norrländska landskapen. Där får excerpisten ofta acceptera att belägg saknas. Eftersom de nordligare socknarna är så vidsträckta, kan man heller inte i samma utsträckning som i de sydligare landskapen använda sig av reservsocknar. Den relativa bristen på norrländskt material är alltså något man ska vara medveten om. $^{2}$

Begrepp nummer 115 i ALE:s frågelista gäller benämningen på den fågel som på franska heter le rossignol, vilket på svenska motsvaras av näktergal.

Enligt SAOB avser näktergal »fågeln Luscinia luscinia Lin., som är känd för hanens melodiska sång, som han utför särsk. nattetid l. på kvällen; i sht zool. äv. om andra arter av släktet Luscinia Brehm, i sht L. megarhyncha Brehm, som häckar bl. a. i mellersta Europa «. ${ }^{3}$

1 ALE finansieras av UNESCO.

2 Metoder, principer och problem inom ALE-arbetet beskrivs närmare i Söderberg $1999 \mathrm{~s}$. $53 \mathrm{f.}, 64 \mathrm{f}$.

3 SAOB art. näktergal. 
Näktergal, Luscinia Iuscinia. Foto: Daniel Bastarja (CC BY-SA 3.0).

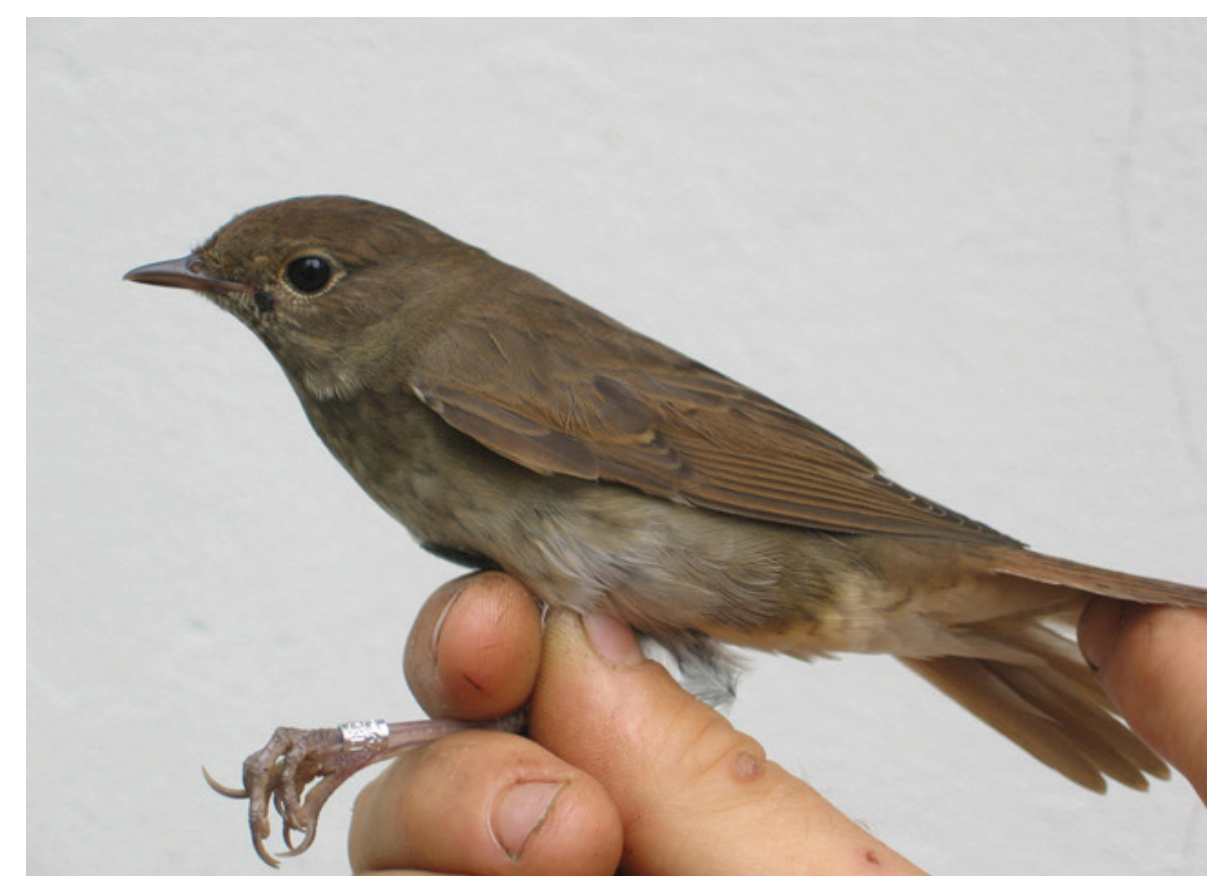

Den fågel vi i Sverige kallar näktergal är emellertid inte samma art som den man i England kallar nightingale och i Tyskland Nachtigall. Där syftar benämningen på den sydliga näktergalen, Luscinia megarhynchos, som avlöser vår näktergal nere i västra Europa. Det vi kallar näktergal kallar tyskarna Sprosser och engelsmännens benämning är Thrush Nightingale. ${ }^{4}$

Näktergalens häckningsmiljö består av (helst fuktig) lövskog med lummig undervegetation eller tätt buskage. Fågeln håller gärna till på marken och vill därför också ha markytor med sparsam vegetation under buskarna. Nattetid sjunger den flitigt under maj månad, men redan i början av juni avtar sjungandet. I Sverige har den en sydlig-östligmellansvensk utbredning. Fågeln var på tillbakagång under 1800-talet och i början av 1900-talet, men har från och med 1930-talet långsamt börjat öka i Syd- och Mellansverige. Den pågående igenväxningen av landskapet har frambringat fler gynnsamma miljöer för näktergalen. ${ }^{5}$ Längs kusterna kan den numera till och med påträffas långt norrut. $^{6}$

Efter 1980-talet har emellertid näktergalens ökning och spridning i landet upphört och under de senaste cirka 30 åren har man noterat en tillbakagång. ${ }^{7}$

Näktergalen har ett oansenligt yttre ${ }^{8}$ och skulle troligtvis ha förblivit en närmast okänd fågel och det inte varit för dess karaktäristiska och mycket ljudliga sång. ${ }^{9}$ Näktergalen har under en längre tid använts som sinnebild i poesi, skönprosa och annan vitter stil. Därigenom har begreppet näktergal, om inte annat så i dess bildliga betydelse, väl kommit att bli allmänt känt. Egentligen är det från början dess sång, som hos Staav m.fl.

\footnotetext{
4 Lundegårdh \& Wahlström 1992 s. 153, Staav m.fl. 347-348.

5 Staav m.fl. 1987 s. 347 f.

6 Lundegårdh \& Wahlström 1992 s. 153.

7 Ottvall m.fl. 2008; Ottosson m.fl. 2012.

8 Se bild 1.

9 Staav m.fl. 1987 s. 347.
} 
beskrivs som »mer melodisk och vacker«, man tänkt på när man liknat exempelvis en välljudande sångröst eller stämma vid näktergalssång. ${ }^{10}$ Enligt Lundegårdh \& Wahlström är det egentligen sydnäktergalen ${ }^{11}$ som har den vackraste stämman. Sången hos vår nordliga näktergal karaktäriseras mer av sin sonoritet än av sin skönhet; den lär kunna höras på ett par kilometers avstånd. ${ }^{12}$ Den verkliga storsångaren hos oss är kanske i stället koltrasten. ${ }^{13}$

Ordet näktergal äger motsvarigheter i de andra nordiska språken. I isländskan heter det nceturgali m., i färöiskan náttargali n., i norskan nattergal Luscinia luscinia (norsk nattergal 'taltrast') och i danskan nattergal. ${ }^{14}$

Det nusvenska ordet näktergal mask. (fornsv. ncektergala) är ett lån från medellågtyskans nachtegale, vilket motsvaras av fornsaxiskans och fornhögtyskans nachtigala (tyska nachtigall) samt av anglosaxiskans nihtegale (engelska nightingale). Fågelbeteckningen finns alltså enbart i de västgermanska språken och betyder 'den som sjunger om nätterna'. Förleden är identisk med ordet natt och senare leden är bildad till verbet gala som betyder 'sjunga eller kraxa (om fåglar); skrika'. ${ }^{15}$ Benämningen tyder på att fågeln från Tyskland invandrat till Norden. Den svenska formen med æ och $r$ beror förmodligen på inverkan från inhemska fsv. gen. ncetter- till natt. ${ }^{16}$

Hellquist konstaterar att näktergalens sång »först jämförelsevis sent väckte någon större uppmärksamhet «, och nämner som exempel att den i tysk poesi inte spelar någon roll före 1000-talet. I svenska handskrifter från medeltiden omtalas näktergalen mestadels i religiös översättningslitteratur. ${ }^{17}$

Ett belägg på näktergal ur riddardiktningen påträffas i Herr Ivan Lejonriddaren, som ingår i de s.k. Eufemiavisorna. De har enligt Valter Jansson tillkommit senast vid 1300-talets mitt, och språket tyder på sydvästsvensk proveniens. ${ }^{18}$ Här citeras det sammanhang vari belägget förekommer. ${ }^{19}$

Tha iak hafdhe ligath ena stund ij dwala, tha hördhe iak ater the näktergala ok andra foghla medh söte röst; mit hiärta gladdis ok fik ena tröst.

De nysvenska förekomsterna i SAOB visar att ordet näktergal mycket ofta förekommer som metafor i poetisk och vitter stil. Mindre vanligt tycks det vara att näktergal syftar på

$10 \quad$ Staav m.fl. 1987 s. 348.

11 Exempel på sydnäktergalens sång: http://www.youtube.com/watch?v=BnjAtIWvzDQ

12 Så här låter vår egen näktergal: http://www.youtube.com/watch?v=bMl4KTV3ZxU

13 Lundegårdh \& Wahlström s. 153. Som en jämförelse kommer här ett prov på koltrastens sång: http://www.youtube.com/watch? $\mathrm{v}=130$ sb8opmQ

14 Se gängse ordböcker.

15 SAOB art. gala.

16 Hellquist art. näktergal.

17 Hellquist art. näktergal.

18 Jansson 1945 s. 308, 236, 313.

19 Citatet är hämtat ur Erik Noreens upplaga, SFSS bd 50. 
fågeln som sådan. Se här några exempel på hur näktergal används under nysvensk tid. Stiernhielm tänker sig näktergalen som ett kvinnligt väsen och skaldar

Små foglar leeka, pittra, springa;

Fru Nachtigal man hörer klinga ${ }^{20}$

Vanligt är att välsjungande fåglar av olika slag kallas för näktergal, då med framförställt adjektivattribut: Nordens näktergal kan vara en benämning på taltrasten (jfr ovan norsk nattergal), fjällens näktergal eller lapsk näktergal syftar på blåhakesångaren och med mindre näktergal avses trädgårdssångaren.

Som metafor för skönsjungande människor (främst kvinnor?), har näktergalen också kommit till användning. Ett av de mest bekanta exemplen är den svenska näktergalen och Nordens näktergal som var benämningar på den svenska sopranen Jenny Lind. ${ }^{21}$

Sammanfattningsvis kan sägas om näktergalen att den är en invandrad fågel med begränsad utbredning i landet. Den har ett anspråkslöst yttre och dess habitat är sådant att den inte gör sig särdeles bemärkt. En begränsad tid av våren och försommaren låter den höra sin ljudliga sång som hörs vida omkring, men det är allt. I skönlitteraturen har den dock fått stor plats, framför allt som sinnebild för skönsång och poesi. Vilken roll spelar denna fågel i det dialektala ordförrådet?

En genomgång av uppteckningarna för de 178 karteringspunkterna visar att näktergal, med undantag för den sydligaste delen av landet, är utomordentligt svagt belagt i dialekterna - sammanlagt har noterats endast 24 belägg. Någon synonym till ordet har inte påträffats. Belägg saknas till och med från stora delar av det område där näktergalen förekommer, medan enstaka belägg finns norr om fågelns utbredningsområde: Resele socken i Ångermanland och Norrala socken i Hälsingland. En säker slutsats kan dras: i svenska dialekter finns ett enda ord för Luscinia luscinia, och det är näktergal.

För att möjligen kunna komplettera dialektuppteckningarna, gjordes också en sökning i NAU:s naturnamnsregister. Resultatet blev inte överväldigande. Följande belägg på näktergal som ortnamnsled påträffades: Näktergalen, holme i Värmdö socken, Södermanland, Näktergalen, hagmark, Norra Fågelås socken, Västergötland (enligt upptecknarens noteringar har där förr funnits näktergal) samt Stora o. Lilla Näktergalsskäret, S:t Ibbs socken, Skåne. I samtliga fall, utom kanske det västgötska, finns möjligheten att namnen är litterärt inspirerade. Skärgården är ju som bekant inte fågelns naturliga livsmiljö. Som ortnamnsled synes näktergal med andra ord ha spelat en underordnad roll.

De få beläggen till trots, uppvisar benämningen på Luscinia luscinia en stor formrikedom. ${ }^{22}$ Näktergal vilket är identiskt med riksspråksuttalet, utgör den numerärt sett största gruppen i detta material, låt vara att beläggen inte är fler än åtta. De flesta hör hemma i Skåne och Halland. Som ett isolerat fall framstår belägget näktergal från Nora socken i Uppland. Frågan är hur detta uttal ska bedömas. Är det en genuin dialektform eller

20 Citatet är enligt SAOB art. näktergal hämtat ur Georg Stiernhielm, Parnassus Triumphans. Ballet. (i: Musce Suethizanthes) Sthlm 1668.

21 För fler exempel på användning av näktergal under nysvensk tid, se SAOB art. näktergal.

22 De olika dialektformerna är återgivna med normalortografi. 
ett läsuttal? Uppsvenskan är ju en dialekt som i mångt och mycket ligger riksspråket/ skriftspråket nära. ${ }^{23}$

Formen näktegal (fyra belägg), utan $r$, kan lokaliseras till de sydsvenska landskapen Skåne, Blekinge och Småland. Att $r$ lätt faller i inljud är välbekant inom dialektologin.

Näktagal är uteslutande en gotländsk form. Den finns också belagd i Laumålsordboken. ${ }^{24}$ Frågan är om den ska uppfattas som en analogisk ombildning efter sammansättningar med bindevokalen $a$. Möjligen skulle också näktegal kunna tolkas på samma sätt, alltså ombildning efter sammansättningar där bindevokalen har försvagats till $e$.

Hos formen nättergal föreligger en tydlig inverkan från den genitivformen nætter (jfr ovan). För övrigt har övriga nordiska språk form med -t(t)- i förleden (se ovan). Det är bara Sverige som har kvar -kt-. Denna förbindelse strider ju egentligen mot nordisk fonotax, och i dialekterna har den på sina håll assimilerats till -tt-. ${ }^{25}$ Nättergal (sammanlagt sex belägg) är den form som uppvisar störst geografisk spridning i detta material. Den finns så långt norrut som i Ångermanland och Hälsingland och uppträder även i Norrbärke socken i södra Dalarna. Resterande belägg härrör från Skåne och Småland. Vad de sydsvenska landskapen beträffar kan måhända närheten till Danmark ha spelat viss roll för formens utveckling.

Nättegal utan $r$ är belagt endast en gång, nämligen i Lerums socken i Västergötland. (Jfr ovan formerna näktegal och näktagal som inte heller har inljudande $r$. Kan det vara fråga om en analogisk ombildning som föreslagits ovan, eller är det helt enkelt exempel på bortfall av inljudande $r$ ?)

Formen nättsgal i nordvästra Småland (Åsenhöga socken) avviker från andra upptecknade former såtillvida som att det är den enda form som har ett $s$ i fogen. Det här är en mycket tydlig anpassning till svensk ordböjning.

Formen nöttagal är uteslutande belagd i Mörrums socken, Blekinge och är den enda upptecknade form där förledens stamvokal har labialiserats till ö. Även här kan man misstänka att ordformen anpassats efter svenskan.

Ännu en avvikande form utgör näkkegal från Persnäs socken på Öland. I inget annat fall har förledens -kt- assimilerats till -kk-. Det får väl ses som en variant till assimilationen $-k t->-t t-$.

Det knappa materialet för ordet näktergal medger inga långtgående slutsatser mer än att det inte finns någon annan benämning för Luscinia luscinia i svenska dialekter än just näktergal. Det är väl heller inte troligt att näktergalen har spelat så stor roll i allmänhetens medvetande, utan mer kommit att bli ett litterärt och poetiskt begrepp som inte hör hemma i dialekterna. Självklart finns också möjligheten att personer som har varit ute på fältet och upptecknat dialektmaterial kan ha förbisett att fråga om denna oansenliga fågel, som egentligen bara gör väsen av sig under en begränsad del av året. Det har kanske också sin betydelse att näktergalen under stor del av den tid som dialektuppteckningar

23 Wessén s. 30 ff., i sht s. 37 f.

24 Laumålsordboken, häfte 11, artikel näktergal.

25 Hellquist, artikel natt. 
gjordes i Sverige, var på tillbakagång. Det fanns sällan anledning att uppmärksamma näktergalen i det dagliga livet.

Med tanke på det begränsade materialet, får väl ändå sägas att formrikedomen är ganska stor och en försiktig slutsats är att språkbrukarna på sina håll har reagerat mot förbindelsen -kt- så att den har assimilerats till -tt- eller, som på Öland, till -kk-. Det finns också tecken som tyder på att förleden på analog väg anpassats till svensk ordbildning med fogevokaler $(a, e)$ eller genitiv-s i sammansättningsfogen. Hur uttalsformerna ser ut i resten av landet är omöjligt att ha någon bestämd uppfattning om, men ett rimligt antagande är väl att läsuttalet »näktergal« är vad kan vänta på de flesta håll. Oavsett om man har denna högljudda lilla sångare i sin närhet eller ej, känner man helt säkert till dess existens och tvekar inte att använda uttryck som »Lee Marvin sjunger som en näktergal« och liknande.

Nu återstår att höra om någon liten pigg näktergalshane börjar drilla för Per på hans stora dag. Det är både rätt tid, försommar, och rätt plats, mitt i Småland.

\section{Källor och förkortningar}

\section{$\mathrm{ALE}=$ Atlas Linguarum Europae}

ALE:s frågelista = Atlas Linguarum Europae. Premiere questionare, onomasiologie, vocabulaire fondamental préparé par Joep Kruijsen (1976). Assen/Amsterdam. Pays-Bas.

Hellquist = Hellquist, Elof (1980), Svensk etymologisk ordbok. 1-2. 3 uppl. 4 tryckn. Lund. Herr Ivan Lejonriddaren (1931). Kritisk upplaga utgiven av Erik Noreen. SFSS Bd 50.

Uppsala.

Jansson, Valter (1945), Eufemiavisorna. En filologisk undersökning. Uppsala \& Leipzig.

Laumålsordboken = Klintberg, Mathias \& Gustavsson, Herbert (1997), Ordbok över Laumålet på Gotland, h. 11. Skr. Utg. genom Dialekt- och folkminnesarkivet i Uppsala. Uppsala.

Lundegårdh, Lennart \& Wahlström, Sten (1992), Från alfågel till ärtsångare. En bok om svenska fåglar. Bokförlaget Bra Böcker AB.

NAU = Namnarkivet i Uppsala

Noreen, Erik. Se Herr Ivan Lejonriddaren.

Ottosson, U., Ottvall, R., Elmberg, J., Green, M., Gustafsson, R., Haas, F., Holmqvist, N., Lindström, Å., Nilsson, L., Svensson, M., Svensson, S. \& Tjernberg, M. (2012), Fåglarna i Sverige - antal och förekomst. Sveriges Ornitologiska Förening, Halmstad.

Ottvall, R., Edenius, L., Elmberg, J., Engström, H., Green, M., Holmqvist, N., Lindström, Å., Tjernberg, M. \& Pärt, T. (2008), Populationstrender för fågelarter som häckar i Sverige. Naturvårdsverket Rapport 5813.

SAOB = Svenska Akademiens ordbok ([1893-] 1898 ff), utg. av Svenska Akademien. 1 -. Lund.

SFSS = Samlingar utgivna av Svenska Fornskriftsällskapet. 1- (1844-). Stockholm \& Uppsala.

Sofi = Institutet för språk och folkminnen

Staav, Roland, Franson, Thord \& Langvad, Steen (1987), Nordens fåglar. København \& Stockholm. 
Svlm = Nyare bidrag till kännedom om de svenska landsmålen och svenskt folklif från 1898. Bidrag [...] från 1904: Svenska landsmål ock (och) svenskt folkliv. [Tidskrift tidigare utg. av ULMA, numera av Kungl. Gustav Adolfs Akademien.]

Söderberg, Gunilla (1999), Bröllops-besvär. Kommentar till ett ALE-begrepp. I Svlm 1999. Wessén = Wessén, Elias (1970), Våra folkmål. Lund. 